\title{
Refugee education: Education for an unknowable future
}

\section{Citation}

Dryden-Peterson, Sarah. 2017. Refugee Education: Education for an Unknowable Future.

Curriculum Inquiry 47, no 1:14-24.

\section{Published Version}

doi:10.1080/03626784.2016.1255935

\section{Permanent link}

http://nrs.harvard.edu/urn-3:HUL.InstRepos:30780126

\section{Terms of Use}

This article was downloaded from Harvard University's DASH repository, and is made available under the terms and conditions applicable to Open Access Policy Articles, as set forth at http:// nrs.harvard.edu/urn-3:HUL.InstRepos:dash.current.terms-of-use\#OAP

\section{Share Your Story}

The Harvard community has made this article openly available.

Please share how this access benefits you. Submit a story.

\section{Accessibility}




\title{
Refugee Education: Education for an Unknowable Future \\ Sarah Dryden-Peterson
}

\section{Contact Information}

Sarah Dryden-Peterson (Corresponding Author)

Harvard Graduate School of Education (Institutional Affiliation)

6 Appian Way

Cambridge, MA 02138

Tel: (617) 435-2344

Email: sarah_dryden-peterson@gse.harvard.edu

\section{Acknowledgements}

The author wishes to thank the teachers, students, agency staff, and other community members who have been involved in field-based research that informed this article. Thank you also to research collaborators, including Jacques Bwira, Kyohairwe Sylvia Bohibwa, and Negin Dayha.

\section{Funding}

Research that informed this article was funded by the Fulbright Commission, the Mellon Foundation, the Harvard Graduate School of Education, the Weatherhead Center for International Affairs at Harvard University, and the National Academy of Education/Spencer Foundation.

\section{Research Ethics}

All research drawn upon in this essay was reviewed by the Committee on the Use of Human Subjects at Harvard University. All interview participants were aware of my role as an academic researcher and provided with an information sheet about the research, its potential risks and benefits, and their rights within the research; all gave their oral consent for participation.

\section{Disclosure Statement}

The author holds no financial interest or benefit arising from the direct applications of this research.

\begin{abstract}
Conflict and displacement are increasingly protracted, requiring rethinking of refugee education as a long-term endeavor, connected not only to the idea of return but to the on-going nature of exile. In this essay, I examine how refugees conceptualize education and its role in creating certainty and mending the disjunctures of their trajectories as refugees. Through a portrait of one refugee teacher, the essay explores technical, curricular, and relational dimensions of refugee education that assist refugee students in preparing for unknowable futures.
\end{abstract}

\section{Keywords}

Refugee, conflict, teachers, purposes of education 


\title{
Refugee Education: Education for an Unknowable Future
}

\begin{abstract}
Conflict and displacement are increasingly protracted, requiring a rethinking of refugee education as a long-term endeavor connected not only to the idea of return but also to the ongoing nature of exile. In this essay, I examine how refugees conceptualize education and its role in creating certainty and mending the disjunctures of their trajectories as refugees. Through a portrait of one refugee teacher, the essay explores technical, curricular, and relational dimensions of refugee education that assist refugee students in preparing for unknowable futures.
\end{abstract}

\section{The Uncertainties of Contemporary Conflict}

Abroon $^{1}$ arrived in Dadaab refugee camp in Kenya when he was nine. He and his family initially thought they would quickly return to Somalia. Yet twenty-three years later, Abroon is still in exile, still living in Dadaab. Abroon is one of 21.3 million refugees globally who have been forcibly displaced outside of their country of origin (UNHCR, 2016). Mainstream media would have us believe that the refugee crisis generated by the contemporary conflict is Syria is unprecedented. It is true that the number of refugees globally is at its highest level since World War II and that, in 2015 alone, 1.8 million people were newly displaced to become refugees (UNHCR, 2016, p. 2). The most recent mass movements have resulted primarily from conflict in Syria, but also with the onset and re-ignition of conflicts in Iraq, Mali, and South Sudan, among others.

Further, Abroon's experience is just one example of how the phenomena of forced migration and exile are not new. The 1.8 million newly displaced refugees in 2015 joined almost 
17 million others who have remained refugees for multiple decades, from on-going conflicts in Afghanistan, Democratic Republic of Congo (DRC), and from Abroon's country of origin, Somalia. Historically, 40 million people were displaced across Europe by the end of World War II. Independence movements across Africa saw more than 850,000 people become refugees in the single year of 1965. Between March and May of 1971, more than 100,000 people per day entered India from East Pakistan; by the end of 1971, there were 10 million refugees in India. One million refugees crossed from Rwanda into what was then Zaire in July 1994, 15,000 each hour on one day (UNHCR, 2000, pp. 51, 52, 59).

The degree of uncertainty that refugees face has changed since the end of the Cold War (Collier, Hoeffler, \& Söderbom, 2004). Critical for refugee education is that conflict and conflict-induced displacement are increasingly protracted (Dryden-Peterson, 2015). For example, between 2005 and 2015, two fifths of all refugees were displaced for three or more years at any one time, and, in 2014, in 33 protracted conflicts globally the average length of exile was 25 years. The current length of displacement is nearly three times as long as it was in the early 1990s (Crawford, Cosgrave, Haysom, \& Walicki, 2015; UNHCR \& Global Monitoring Report, 2016).

Previously, with an understanding that conflict was short-lived and that return from exile would be imminent, refugee education was conceptualized as a return to "normalcy" through the provision of access to schooling (Nicolai \& Triplehorn, 2003). As Davies and Talbot wrote, "the implication [of this thinking] is that it would almost be enough to get the children back into school and that the routines of schooling are as important as its content" (2008, p. 513). Understanding that conflict and displacement are not temporary requires a rethinking of refugee education as a long-term endeavor, connected not only to the idea of return but to the on-going 
nature of exile. In this essay, I examine how refugees conceptualize education and its role in creating certainty and mending the disjunctures of their trajectories as refugees.

\section{The Shifting Landscape of Refugee Education}

When Abroon was young, his mother told him, "I want to educate these [refugee] children so that tomorrow they help themselves and they also help us." Abroon has taken on this responsibility on behalf of his mother. He now teaches in a refugee camp secondary school. "I'm making a good contribution to society," Abroon says, "because I am building their brains and their future. Teachers of refugees play a central role in helping their students to conceptualize what that future might be and how to prepare for it.

Teachers of refugees play this role within the confines of interactions among global and national structures governed by the politics of migration, funding sources, local economies, and the state of national education systems, among other factors (Dryden-Peterson, 2015). The United Nations High Commissioner for Refugees (UNHCR), the global organization mandated with the protection of refugees' rights and the provision of services, including education, poses three "durable solutions" for refugees, in effect three possible futures. They are: return to the country of origin; integration in a country of first asylum (usually a low-income country); or resettlement to a third country (usually a high-income country).

Yet for Abroon, as for most refugees globally, none of these options is a realistic possibility. It has not been safe for him to return home; his country of origin, Somalia, has been engulfed in conflict for almost three decades, among the top countries of origin for refugees in every year since 1988 (UNHCR, 2016, p. 56). He has not been able to integrate into Kenya, because he does not have the right to work and xenophobia toward refugees is high (Foulds, In 
press). And he cannot access resettlement, an option that is available to less than one percent of refugees globally (UNHCR, 2014). His situation is one of "radical uncertainty," where there is imperfect knowledge and the future is unpredictable (Horst \& Grabska, 2015). Faced with an unknowable future, Abroon envisioned that his education might facilitate mobilities - physical and cognitive - that would help him to build a more certain future.

Like most refugees globally, however, Abroon's mobility is restricted. His access to social services and to the protection of his rights is tied to his residence in a refugee camp, limiting his freedom of movement (Lindley, 2011). And yet, it is the very concept of mobility that has shaped his educational experiences to date and that drives his future aspirations. As Abroon said:

education is a very key tool. When war breaks out, you run away... leaving your everything. If you don't have education, then you'll become poor. But if you run away with only your shirt and you have the brain, you can work somewhere and earn a living.... Education is a very essential tool. Also, education is light. Education is the "light at the end of the tunnel," Madad, fellow teacher in Dadaab and colleague to Abroon, said. Yet Abroon was thinking of a different kind of light; he meant that education is not heavy. The lack of weight meant that it was portable. Education was mobile, just as Abroon hoped that his future would be.

To examine how refugees conceptualize the role of education in creating certainty and mending the disjunctures of their trajectories as refugees, I present a portrait of Bauma Benjamin. Bauma, as a teacher, a parent, and a student has navigated educational structures and created educational opportunities across multiple spaces: in his conflict-affected country of origin, Democratic Republic of Congo (DRC); in his country of first asylum, Uganda; in his 
country of resettlement, Canada; and as a transnational actor on issues of refugee education. I do not present Bauma's experiences as a journey to be reified but rather as one of many possible trajectories. His experiences of multiple contexts of conflict, exile, and migration, and the meaning he makes of each one, illuminate the roles of education in the unknowable futures inherent to refugeehood and the ways in which individuals can navigate, and shift, the structures that circumscribe them.

Portraiture is a qualitative social science methodology that intentionally seeks to pursue, understand, and convey the "authority, knowledge, and wisdom" of the perspectives and experiences of research participants (Lawrence-Lightfoot \& Davis, 1997, pp. xv, 103). It involves intense engagement of the researcher and research participants in dialogue and coconstruction of knowledge. This portrait draws on multiple sources of data, which derive from several discrete studies related to refugee education in Uganda (see, for example, DrydenPeterson, 2003, 2006a, 2006b, 2011). For this essay, I draw on original data that I collected, including 12 hours of life history interviews; three one-hour semi-structured interviews in the context of Bauma's work as a teacher at a research site; seventeen interviews with Bauma's students and their families; and participant observation at Bauma's schools over six years; these research endeavors have also grown into a 14-year relationship with Bauma and his family. Most of the interviews and conversations between Bauma and myself were in French, although some were in English; I have done all of my own translations to English, yet I have certain short fragments of text in French, with English translations that follow, in order to signal the language of the setting. Interviews with students and families were conducted in several Bantu languages, with the assistance of a long-term translator and research assistant. 
I deliberately frame the portrait of Bauma with the vignette of Abroon, above, drawn from long-term research with Somali refugees in Kenya with colleague Negin Dahya (see, for example, Dryden-Peterson, Dahya, and Adelman, under review; and Dahya and DrydenPeterson, 2016). While their experiences and meaning-making differ in multiple ways, I am compelled by the resonance across contexts of the dilemma of what education for an unknowable future consists of. I argue that the resonance of this dilemma, and the ways in which refugees navigate it, provides an important framework for understanding and re-imagining the curriculum of refugee education.

\section{Navigating Uncertainty and Disjuncture through Education: A Portrait}

Bauma Benjamin sits on the edge of a wooden chair. It has big, thick armrests and overstuffed blue cushions on the seat and back, and there is a bright yellow embroidered doily carefully draped across the top, behind Bauma's head. It is almost seven o'clock in the morning and, in the equatorial country of Uganda, that means the sun has just risen, no matter the time of

year. The room is dark, though. There are no windows pushed through the concrete walls and the lacy, white curtain that covers the one, narrow doorway to the outside has not yet begun its fluttering dance in the as yet calm and windless morning.

This may be the one time of day that Bauma is alone, that his guard is down, that his mind is quiet. His two children are at the back of the house, in the little laneway that separates this row of concrete homes from the next. In the rainy season, the laneway fills with a creek of dirty, sewage-like water and flocks of malarial mosquitoes. This time of year, this time of morning, it is filled with soapy and laughing children. The children splash water from brightly colored plastic basins onto their still-warm-from-sleep skin and wriggle with the chill. The lucky 
ones, those for whom a day of learning stretches ahead of them, know that every inch of their bodies must be clean before putting on the perfectly washed and pressed white shirts of their school uniforms. Bauma's children are among the lucky ones.

This was not always so. When Bauma arrived in Kampala, Uganda's capital, in 2000, there were no schools that accepted refugee students (see, Dryden-Peterson, 2006a; Turney \& Dryden-Peterson, 2015).

“They do not know that we are refugees," Bauma says of his children. "[My son] knows that he is Congolese, he knows that he comes from Goma. He knows that his grandmother and grandfather are in Goma. [My daughter] knows that also. They do not think they are Ugandans, but they do not think we are refugees." But not a day goes by when Bauma is not reminded that he is a refugee. The Bauma of home, the husband, the father, does not dare enter the streets of Kampala as himself.

When he kisses his wife goodbye and walks away from his immediate neighbors, he becomes a different person. Small in stature no matter the situation, in the streets of Kampala Bauma becomes small in presence. His eyes are always focused on a destination, never a face. His body, stiff and rigid, weaves between the crowds of people shining shoes, selling tomatoes, walking to their myriad destinations. The broad smile that is always on his face when he is in the company of family and friends seems to have forever disappeared. So changed is his look and disposition that he is unrecognizable.

And that is his goal. Bauma was a human rights activist in Congo. His work began on a very personal level, protesting the persecution of his minority Bahunde ethnic group in his home districts of Walikale and Massisi. As the conflict in Congo grew and grew, he became involved with a non-governmental organization that fought, more visibly and in many districts, for the 
rights of civilians. Government forces and rebel militia are powerful in Eastern Congo; over five million people have been killed there since 1998 - the highest death toll in any part of the world (Council on Foreign Relations, 2015). While this massive conflict seems to escape the world's attention, the human rights activities of a small group could not escape the attention of the authorities. Bauma was imprisoned and tortured, only to escape when a fire spread through the prison and the guards fled to protect themselves. The International Committee of the Red Cross then helped him to find exile in Uganda.

Before conflict erupted, Bauma had pursued his teaching diploma in DRC, inspired by his father who was a teacher and revered as a peacemaker in their community. Bauma often describes teaching as his "calling." He has a keen responsibility to teach children, wherever he might find them. As DRC is a country of dense forests and spread-out villages, he knew that he might find himself in a situation where all he had were a group of children and the shelter of a tree. No matter the difficulty, no matter how remote, no matter how distant from a world of schools, Bauma would teach these children. When he arrived in Kampala, he found himself, he said, "as someone who is in the forest." A dense urban forest, perhaps, but one in which groups of children, especially refugee children, were not even privy to the shelter of a tree.

Without so much as a bunch of matoke (green bananas) to feed his own family, Bauma dedicated himself to building a school. "What prompted me [to start this school]," he said, was that "there were many refugee children who did not go to school, they passed their days in the street, just like that." Bauma's idea of "building" a school was not to construct a physical structure but rather to gather a corps of teachers, those who would inspire learning in Kampala's refugee children. "A school is not the building," Bauma often says; "it is the teachers." The space of the school that Bauma started in Kampala shifted constantly: a room in a church 
leader's home, where the children rolled up their sleeping mats and blankets each morning to make space to sit (2000-2002); the cavernous, windowless, and doorless space of a church under construction where children of all ages placed benches on the dusty floor, stacked one high for seats, two high for desks (2003-2004); a local school where they shared space with Ugandan national children (2005-2006); a brand new stand-alone classroom, built with boards and dirt, paid for with funds from the French Embassy (2007-2009); and refurbishment and extension of that classroom into a full school with concrete walls and floors and a tin roof, with funding from UNHCR and registered with the Uganda Ministry of Education and Sports (2010 to the present). Yet to the question of who pays his salary, Bauma had a one-word answer: "Personne" (no one). Despite the struggle this lack of compensation presented for Bauma and his family, he was unwavering in his presence, consistently demonstrated a deep care for his refugee students, and acted on his own goal of inspiring learning. In addition to his father, Bauma remembers two other important teachers in his life: an old man by the name of Leonard who answered every question his students asked; and Sidonie, a young woman from his community who also "was our neighbour." Bauma said, "she fed us, she carried me [when I could not walk through the mud]." I see these two teachers echoed repeatedly in Bauma's interactions with his students. Bauma calls every student by name; he makes sure to hear the voice of each student during every lesson. This personalized attention is rare in refugee classrooms, as in the classrooms of Bauma's DRC home and across many developing contexts (see, for example, Mendenhall et al., 2015; Schweisfurth, 2015). Instead of writing a list of vocabulary words on the sole fragment of chalkboard he has, Bauma writes “J'apprends du vocabulaire” (I learn vocabulary), placing each student in a powerful role as active learner. At the end of each lesson, Bauma says to his 
students, "merci beaucoup pour aujourd'hui" (thank you for today). When I visit each of the students' homes with Bauma, he is welcomed as a friend and a frequent guest.

Through his teaching and these kinds of interactions, Bauma explains that he has two goals for his students. First, that they learn to be part of life in Uganda for now and, second, that they learn what they need to know to prepare them for their futures. But what would these futures be? This was the question with which Bauma was preoccupied, for himself and for his students. For himself, Bauma's preferred future was to return home to DRC. “In one's own village" is where one really feels at home, he says. It is a place where the future can be certain. But in the context of on-going war and "no rule of law," where "you could be killed no matter when for no matter what reason," that future is not possible. Bauma has come to the conclusion that home, then, is what he can build for himself, his students, and his children wherever they are. When you become a refugee, Bauma says, "you must begin to live here [where you are], from the moment you arrive." Bauma has tried to create opportunities for his students to build a life in Uganda by enabling them to go to school and continue to learn. For himself, however, Bauma states, "I have failed at integration." It is his own inability to continue studying that led him to lose faith in the possibility of integration to Ugandan society as a possible future.

Bauma's own schooling was interrupted by conflict, repeatedly. He only just had the chance to graduate secondary school with a teaching diploma before fighting closed down the schools in his home area. "I would have preferred to do my studies in Congo," he says. "But the war interrupted all that. Then I was married, now I have ended up in Uganda with the rebels chasing me." And then, even when a research grant I held made funding available to pay for Bauma's continued education, Makerere University refused him entry in 2005. I stood with Bauma at the admissions counter as the woman explained that based on the fact that his high 
school diploma was in French, he could not be admitted. This restriction made it impossible for anyone educated in DRC to enter the university, effectively barring all Congolese refugees. More discouraged than I have ever seen him, Bauma lamented: "I know that I am still young. I know that my memory is good. But, I know [now] that the chances for me to study are small." The trajectory of long-term exile in Uganda that Bauma had imagined for himself, enabled by furthering his education, shriveled up in that moment.

With education denied, Bauma began to think seriously about the need to leave Uganda. "If, last year, the university would have accepted me," he said, "I would not have thought any further about resettlement." While Bauma actively pushed his resettlement case with UNHCR, he remained committed to creating possible futures for his students, most of whom he knew did not have any prospects of mobility. He made the decision to change the language of instruction of his school from French to English, in recognition of the slim chances of their return to DRC. He registered the school with the Ugandan Ministry of Education and Sports. Even if he did not have an English-language diploma that would allow him to continue his education, he would ensure that his students did.

Eleven years after arriving in Uganda, Bauma received the news that he and his family now four children - would begin their exile anew. That day, I received an email that read: "J'ai finalement reçu le visa! Finalement à Ottawa!!!!!!!! (I finally received the visa! Finally, to Ottawa!!!!!!!) [My wife], the children and myself have no words to say, we are filled with extreme joy!" Seven days later, they were on an airplane, for the first time, headed for a belowfreezing day in Ottawa. Bauma had spent most of that intervening week making sure that his school in Kampala could continue. His four children, he knew, would be assured of an education in Canada. He also needed to ensure his students could continue building their present lives in 
Uganda and preparing for their as yet unknowable futures. In fact, Bauma admitted to me not long ago that he almost did not get on that airplane, preoccupied with the tension of a future that had opened to him but remained so uncertain for his students.

Five years after arriving in Canada, Bauma's children are settled in their schools, his wife has graduated high school, and after working for three years delivering furniture, Bauma himself has finally begun his post-secondary education. Now eligible for Canadian citizenship, Bauma's future seems more certain - more knowable - than at any time since his flight from DRC. From this place of greater security, Bauma's primary commitment continues to be to inspire learning in the refugee children of Kampala in order that they might build more certain futures. Once a year since his arrival in Canada, he returns to Uganda to work with the teachers at his school, connect with the donors who support it, visit each family, and talk with the students.

Bauma's school opened access to education for refugees in Kampala, where there previously was none. His later decision to shift the language of instruction to English and to register the school with the Ugandan Ministry of Education intentionally created opportunities for his students that had not been open to him, including recognized certification of their learning and developing fluency in the language of power in their context of long-term exile. With these shifts, the school has attracted more Ugandan national students. Bauma views this coming together of refugees and nationals as a way of building community in exile, and he has actively sought to foster strong relationships between refugee and national young people. He has, for example, organized trainings for his teachers on how to have conversations about differences, stereotypes, exclusion, and empathy. He has also instituted weekly debates where all of the students at the school engage on such topics as regional political conflicts or government education policies. Bauma believes that in order to prepare his refugee students to navigate their 
futures, he must combine developing skills and confidence in their abilities to empathize and analyze with a deep attention to relationships, including the kind of care and respect that was modeled to him in the way Leonard and Sidonie cared for him and respected his every question.

Bauma's students remain stuck in the uncertainty of exile in a country of continued disjunctures between their aspirations and the opportunities open to them, specifically in lacking pathways to citizenship or the formal right to work (see Dryden-Peterson, 2016). Yet the students have a kind of preparation for this uncertainty that Bauma himself did not. They have access to education and recognized certification; knowledge of the language of power in their context of exile; confidence in their ability to learn; and guided practice at building relationships with Ugandan nationals. Bauma identifies these opportunities and skills as ones his students will need as they not only inherit a future, but create it. Moreover, in the ways Bauma has created - and, through his transnational actions, continues to create - educational opportunities for refugees, he provides on-going hope for his students of the possible fluidity of migration and the pursuit of futures that morph both in response to existing structures and in endeavors to change them.

When Bauma arrived in Kampala, Uganda, he received a letter from UNHCR stating: "This is to certify that the above-named person whose photograph appears below is a Congolese refugee known to this office. Any assistance rendered to him will be highly appreciated." On the bottom of the letter was an expiration date. The idea of an expiration date only confirmed what refugees themselves already know: assistance does expire. The mandate to protect that the global community has conferred on UNHCR is only as good as the funding and political will behind it. Funding for food and shelter dries up; nativism rises as social services in countries of asylum become over-stretched. Bauma's approach to refugee education has been that it alone has no expiration date. 


\section{Education for an Unknowable Future}

The trajectories of refugees do not fit neatly into the established policy categories of return, local integration, and resettlement. Instead, they are non-linear and complex permutations of migration, exile, and consistently re-imagined futures. The experiences of Bauma and his students point to the need to conceptualize refugee education so that it can meet goals of cognitive mobility that accompany long-term uncertainty. Planning for refugees' extended presence in schools, however, is not politically popular. It runs counter to donors' short budgetary cycles, which are often one year only. It can also harden national resentment, both within national contexts that are already over-stretched and struggle to meet the needs of citizens, such as in Uganda, as well as within contexts that are well-resourced, such as in Denmark (Tanner, 2016).

Recent shifts in refugee education policy and practice have made some headway into these political issues, toward reducing some of the uncertainty of refugee futures. Prompted in part by the experiences of students in schools such as Bauma's, UNHCR's Education Strategy now focuses on increasing access to education through integration of refugees in national schools, which have longer funding cycles and, usually, greater stability in teacher quality and certification of learning than refugee-only responses (see also, Dryden-Peterson, 2015; UNHCR, 2012). This approach, however, requires greater coordination between global, national, and local actors, which can draw attention away from the core of learning and teaching. Yet, this coordination is not unimportant; for example, more refugee children had access to school and certification once UNHCR and the Ugandan government worked together to recognize Bauma's school (see also, Turney \& Dryden-Peterson, 2015). 
Beyond technical dimensions, teachers like Bauma are often open to re-envisioning, sometimes radically, the futures of their refugee students, such as the possibility of long-term exile. This future would not be possible without access to education, which Bauma recognized and acted upon, both within and outside of existing structures, to create new possibilities for his students, such as through certification, language learning, and concentrated work toward social cohesion. Further, refugee teachers often reconceptualize power relationships as they enact transformations from rote, discipline-based education to learner-centered approaches, as Bauma did. While these shifts are frequently neocolonial in their external application (Schweisfurth, 2013), in refugee settings they are often in response to the flexibility teachers find their students need for an unknowable future (see also, Mahshi, 2006; Soudien \& Baxen, 1997). In these contexts of uncertainty, teachers are able to harness what Maber calls "creative alternative space of becoming" (Maber, 2016), in which to renegotiate the boundaries of identity and belonging as they construct school environments that are conducive to creating futures, rather than simply inheriting them.

The praxis of refugee education, as lived by Bauma and hundreds of other teachers of refugees whom I have observed and learned from, involves deliberation about the nature of knowledge, self-reflection about purposes and aspirations for education, and engagement with politics and power structures. Critically, the processes and outcomes of these deliberations are inherently connected to the relationships between actors - students, teachers, families, UNHCR, national governments, among others. Looking forward, Bauma's experience points also to the increasing importance of the globalization of implicated relationships, as local actors engage with Diaspora communities and others in virtual and transnational spaces, as Bauma does, 
bringing together resources and power as well as opening up spaces for cognitive, even if not physical, mobility.

\section{Notes}

${ }^{1}$ All names have been changed to protect the identities of research participants. 


\section{References}

Collier, P., Hoeffler, A., \& Söderbom, M., (2004). On the Duration of Civil War. Journal of Peace Research, 41, 253-273.

Council on Foreign Relations. (2015). The Eastern Congo. Washington, DC: Council on Foreign Relations.

Crawford, N., Cosgrave, J., Haysom, S., \& Walicki, N. (2015). Protracted displacement: Uncertain paths to self-reliance in exile. London: Overseas Development Institute.

Davies, L., \& Talbot, C., (2008). Learning in Conflict and Postconflict Contexts. Comparative Education Review, 52.

Dahya, N. and S. Dryden-Peterson (2016). "Tracing pathways to higher education for refugees: the role of virtual support networks and mobile phones for women in refugee camps." Comparative Education: 1-18.

Dryden-Peterson, S. (2003). Education of Refugees in Uganda: Relationships between Setting and Access, Working Paper Series. Kampala, Uganda: Refugee Law Project.

Dryden-Peterson, S., (2006a). 'I find myself as someone who is in the forest': Urban Refugees as Agents of Social Change in Kampala, Uganda. Journal of Refugee Studies, 19, 381-395.

Dryden-Peterson, S., (2006b). The Present is Local, the Future is Global? Reconciling Current and Future Livelihood Strategies in the Education of Congolese Refugees in Uganda. Refugee Survey Quarterly, 25, 81-92.

Dryden-Peterson, S. (2011). Refugee Children Aspiring toward the Future: Linking Education and Livelihoods. In K. Mundy \& S. Dryden-Peterson (Eds.), Educating Children in Conflict Zones: Research, Policy, and Practice for Systemic Change (A Tribute to Jackie Kirk) (pp. 85-99). New York: Teachers College Press.

Dryden-Peterson, S., (2015). Refugee education in countries of first asylum: Breaking open the black box of pre-resettlement experiences. Theory and Research in Education, 1-18.

Dryden-Peterson, S. (2016). "Refugee Education: The Crossroads of Globalization." Educational Researcher 45(9): 473-482.

Foulds, K. (In press). The Somali question: Protracted conflict, national narratives, and curricular politics in Kenya. In D. Bentrovato, K. V. Korostelina \& M. Schulze (Eds.), History can bite: History education in divided and post-war societies. Göttingen, Germany: Vandenhoeck \& Ruprecht.

Horst, C., \& Grabska, K., (2015). Introduction: Flight and Exile-Uncertainty in the Context of Conflict-Induced Displacement. Social Analysis, 59, 1-18.

Lawrence-Lightfoot, S., \& Davis, J. H. (1997). The Art and Science of Portraiture. San Francisco: Jossey-Bass.

Lindley, A., (2011). Between protracted and a crisis situation: Policy responses to Somali refugees in Kenya. Refugee Survey Quarterly, 1-36.

Maber, E. J. T., (2016). Cross-border transitions: navigating conflict and political change through community education practices in Myanmar and the Thai border. Globalisation, Societies and Education, 14, 374-389.

Mahshi, K., (2006). An Inteview with Khalil Mahshi. Harvard Educational Review, 76.

Mendenhall, M., Dryden-Peterson, S., Bartlett, L., Ndirangu, C., Imonje, R., Gakunga, D., et al., (2015). Quality Education for Refugees in Kenya: Pedagogy in Urban Nairobi and Kakuma Refugee Camp Settings. Journal on Education in Emergencies, 1, 92-130. 
Nicolai, S., \& Triplehorn, C. (2003). The role of education in protecting children in conflict. London: Humanitarian Practice Institute.

Schweisfurth, M. (2013). Learner-centred Education in International Perspective: Whose pedagogy for whose development? New York: Routledge.

Schweisfurth, M., (2015). Learner-centred pedagogy: Towards a post-2015 agenda for teaching and learning. International Journal of Educational Development, 40, 259-266.

Soudien, C., \& Baxen, J., (1997). Transformation and outcomes-based education in South Africa: Opportunities and challenges. Journal of Negro Education, 66, 449.

Tanner, A. (2016). Overwhelmed by Refugee Flows, Scandinavia Tempers its Warm Welcome. Washington, DC: Migration Policy Institute.

Turney, A., \& Dryden-Peterson, S. (2015). Should Refugees Live in Cities?, Teaching Cases. Cambridge, MA: Harvard Education Publishing Group.

UNHCR. (2000). The State of the World's Refugees 2000: Fifty Years of Humanitarian Action. Geneva: UNHCR.

UNHCR. (2012). Education Strategy 2012-2016. Geneva: UNHCR.

UNHCR. (2014). Resettlement: A New Beginning in a Third Country. Retrieved 8 December, 2014, from [http://www.unhcr.org/pages/4a16b1676.html]

UNHCR. (2016). Global Trends: Forced Displacement in 2015. Geneva: UNHCR.

UNHCR, \& Global Monitoring Report. (2016). No more excuses: Provide education to all forcibly displaced people. Paris: UNESCO. 